\title{
Eşek sütü ve bazı bileșenlerinin in vitro ortamda antikanser/yara iyileştirme aktivitesinin incelenmesi
}

\author{
Erdal EROĞLU*, Cemre ÖKSÜZ \\ Manisa Celal Bayar Üniversitesi Mühendislik Fakültesi, Biyomühendislik Bölümü, \\ Prof. Dr. Illhan Varank yerleşkesi, Manisa \\ Geliş Tarihi (Received Date): 04.12.2019 \\ Kabul Tarihi (Accepted Date): 05.05.2020
}

\section{$\ddot{O} z$}

Bu çalışmada, eşek sütü, kazein ve kesik süt suyu proteininin in vitro ortamda antikanser ve yara iyileştirme potansiyelinin araştırılması amaçlanmıştır. Öncelikle eşek sütünün pH değeri değiştirilerek kazein ve kesik süt suyu proteinleri elde edilmiştir. Eşek sütü, kazein ve kesik süt suyu proteininin in vitro ortamda insan prostat kanseri hücre hattı (PC-3) üzerindeki antikanser aktivitesi MTT hücre proliferasyon testi kullanılarak incelenmiş olup antikanser aktivite bulunamamıştır. MTT denemelerinde özellikle kazein proteininin \%140 hücre proliferasyonuna sebep olduğu gözlenmiştir. Bu doğrultuda, insan fibroblast hücre hattı (BJ) üzerinde çizik testi uygulanarak bu proteinlerin hücre migrasyonu ve yara iyileştirici etkileri incelenmiştir. Eşek sütü, kazein ve kesik süt suyu proteini $(3200 \mu \mathrm{g} / \mathrm{ml})$ kontrol grubuna klyasla hücre migrasyonunda ve in vitro yara kapanma hızında anlamlı artışa sebep olmuştur. Bu çalışma ile eşek sütünün ve içerisindeki diğer proteinlerin in vitro ortamda antikanser aktivite göstermeyip hücre proliferasyonuna sebep olduğu ve yara iyileştirme amaçl kullanılabileceği gösterilmiştir.

Anahtar kelimeler: Eşek sütü, kazein, kesik süt suyu proteini, antikanser, yara iyileştirme.

\section{Investigation of anticancer/wound healing activity of donkey milk and its some components in vitro}

\begin{abstract}
In this study, it was aimed to investigate the anticancer and wound healing potential of donkey milk, casein and whey protein in vitro. First of all, casein and whey proteins

\footnotetext{
*Erdal EROĞLU, erogluerdal@gmail.com, https://orcid.org/0000-0001-7281-3906

Cemre ÖKSÜZ, cemre.oksuz@outlook.com, https://orcid.org/0000-0002-9700-2656
} 
were obtained by changing the $\mathrm{pH}$ value of donkey milk. The effect of donkey milk, casein and whey protein on anticancer activity on human prostate cancer cell line (PC3) was investigated using MTT cell proliferation assay in vitro and no anticancer activity was detected. In MTT experiments, it was observed that casein protein caused cell proliferation of $140 \%$. Accordingly, cell migration and wound healing effects of these proteins were investigated by applying scratch test on human fibroblast cell line (BJ). Donkey milk, casein and whey protein $(3200 \mu \mathrm{g} / \mathrm{ml})$ caused a significant increase in cell migration and in vitro wound healing rate in comparison to the control group. With this study, it was shown that donkey milk and other proteins in it did not show anticancer activity in vitro but caused cell proliferation and could be used for wound healing purpose.

Keywords: Donkey milk, casein, whey protein, anticancer, wound healing.

\section{Giriş}

Kanser, vücudumuzdaki bir hücrenin kontrol dışı büyümesi, bölünmesi ve anormal şekilde artış göstermesi sonucu oluşmaktadır. Kanser hücresi bulunduğu doku veya organdaki normal hücrelerin kendi görevlerini yapmasını engelleyerek bu bölgeye hasar verir [1]. Kanser yüksek ölüm oranıyla dünya genelinde en yaygın hastalıkların başında gelmektedir. 2012 yılında 8,2 milyon kişi kanser nedeniyle hayatını kaybederken, 5,8 milyon kişinin kanserle mücadeleye devam ettiği ve kanser vakalarının toplamda 14 milyona ulaştı̆̆ 1 kayıtlara geçmiştir. Bu sayının önümüzdeki 20 yıl içerisinde $\% 70$ artarak 2035 yılına kadar 24 milyona ulaşması beklenmektedir [2]. Özellikle erkek bireylerde daha sik görülen prostat kanseri diğer kanser türleri içerisinde dünya genelinde ilk sırayı alırken, ülkemizde en sık rastlanan ikinci kanser tipidir [3]. Bu tablo içerisinde doğal ajanlar geçmişte olduğu gibi günümüzde de kanser araştırmaları için en önemli kaynaklardan biri olmaya devam etmektedir. Antikanser ilaçların \%50'si ya direk olarak doğal ajanlardan, ya da doğadaki moleküllerin taklit edilmesiyle üretilmektedir [4].

Kemoterapi ve radyasyon gibi geleneksel antikanser tedavilerinin oldukça maliyetli olması ve hasta üzerinde ciddi yan etkilere sebep olmasından dolayı daha güvenli ve düşük maliyetli doğal antikanser bileşiklerin keşfi önem kazanmıştır [5]. Son zamanlarda, bitkisel, mikrobiyal ve hayvansal kaynaklı ajanların kanser dahil pek çok hastalığın tedavisinde, enfeksiyon hastalıklarında ve yara iyileşme sürecinde kullanılabileceği gösterilmiştir [5,6]. Doğal bileşiklerin içeriğindeki büyüme faktörleri hücre migrasyonunu, hücre farklılaşmasını ve protein üretimini etkileyerek yara iyileşme sürecinde görev alırken antibakteriyel bileşikler de enfeksiyonu önler [7]. Başarılı bir yara iyileşme süreci inflamasyon, proliferasyon ve maturasyon fazlarının tamamlanması ile gerçekleşir. İnflamasyon aşamasında, yara kan kaybına ve enfeksiyona karşı korunur. Proliferasyon aşamasında, salınan sitokin ve büyüme faktörleri epitel hücrelerin proliferasyonunu ve migrasyonunu sağlar. $\mathrm{Bu}$ aşamanın önemi, dokuların oksijen ihtiyacını karşılamaktır. Maturasyon aşamasında, kollajen üretimi dengeye ulaşır, skar dokusu oluşur ve stabilizasyon sağlanır [7,8]. Özellikle diyabet hastalarında yüksek kan şekeri seviyesinden dolayı damar duvarlarında ve bağışıklık sisteminde sorunlar oluşur, yaralar geç iyileşmeye başlar hatta gangren olabilir $[9,10]$. Özellikle bu tip ağır iyileşme süreci gösteren yaralar doğru şekilde tedavi edilmezse hızlı bir şekilde daha ciddi komplikasyonlara dönüşebilirler. Her ne kadar cilt 
bakımı ve yara tedavi yöntemleri günden güne gelişiyor olsa da, iyileşmeyen kronik yaralar bir yandan hastaların günlük faaliyetlerini olumsuz etkilerken diğer yandan da sağlık kurumlarındaki yükü arttırmaktadır [11]. Dünya çapında yaklaşık 1 milyar hastanın akut ve/veya kronik yaralara sahip olduğu, kronik yaraların yüzlerce insanda deri/doku yıpranmalarına ve organ lezyonlarına sebep olduğu bilinmektedir [12]. Kronikleşmiş yaralara sahip vaka sayısının dünya genelinde artış göstermesi, yara iyileşme sürecinde etkili olacak her ajanı bilimsel olarak değerli kılmaktadır [11].

Günlük tüketilen gıdaların veya bileşenlerinin toksik olmaması, insan sağlığına yarar sağlaması ve toplumda çabuk kabul görmesi nedeniyle kanserle mücadelede yeni ve güvenilir bir yaklaşım olarak ortaya çıkmıştır [13]. Bu gıdalardan biri de; i) besleyici bileşenler bulundurmas1, $i$ ) inek sütü proteinlerine alerjisi olan bireylere alternatif bir besin kaynağı olması ve iii) anne sütüne benzerlik göstermesi sebebiyle besin olarak kullanımı günden güne artış gösteren, eşek sütüdür [14,15]. Diğer süt kaynaklarına kıyasla kazein miktarı düşük olan eşek sütünde yüksek oranda lizozim ve laktoferrin bulunması bu sütün antimikrobiyal özellik sergilemesini sağlamaktadır. Yapılan çalışmalarda eşek sütünün Listeria monocytogenes, Shigella dysenteriae, Salmonella chloreaesuis ve Staphylococcus aureus bakterileri üzerinde antibakteriyel aktivite gösterdiği kanıtlanmıştır [16-18]. Eşek sütü, lenfositlere ve periferik kan hücrelerine sinyal ileten CD69 ve CD25 yüzey reseptörlerinin aktivasyonunu indükler ve interlökin salınımını kontrol eder. Eşek sütü, antibakteriyel enzimler ve anti-alerjen içeriği sayesinde hassas cilde sahip, alerjisi ve aknesi olan kişilerde faydalı olmaktadır. Bu sütün içeriğinde bulunan vitamin ve mineraller cildin yenilenmesi ve sağlıklı kalmasını sağlar [17].

$\mathrm{Bu}$ çalışmanın amacı eşek sütü ve bileşenlerinden kazein ve kesik süt suyu proteinlerinin ayrı ayrı in vitro antikanser ve yara iyileştirme aktivitelerinin araştırılmasıdır.

\section{Deneysel çalışmalar}

\subsection{Malzeme}

İnsan fibroblast hücre hattı (BJ) Dr. Öğr. Üyesi Ersin AKINCI'dan ve insan prostat kanseri hücre hattı (PC-3) Doç. Dr. Harika ATMACA'dan temin edilmiştir. Dulbecco's Modified Eagle's (DMEM) besiyeri, fetal sığır serumu (FBS) ve tripan mavisi gibco firmasından, esansiyel olmayan aminoasit capricorn firmasından, antibiyotik / antimikotik biological industries firmasından, MTT boyası (thiazolyl blue tetrazolium bromide) sigma firmasından, dimetil sülfoksit (DMSO) merck firmasından ve tripsin biowest firmasından satın alınmıştır.

\subsection{Eşek sütünden protein izolasyonu}

Eşek sütü örnekleri Manisa yöresindeki bir eşek çiftliğinden taze sağılmış olarak temin edilmiş ve en kısa sürede laboratuvara getirilip $63^{\circ} \mathrm{C}$ 'de 20 dakika pastörizasyon işlemine tabi tutulmuştur. Pastörizasyon işleminden sonra, süt $4^{\circ} \mathrm{C}$ 'de soğutulup analiz edilene kadar $-20^{\circ} \mathrm{C}$ 'de bekletilmiştir. Süt numunesi $4^{\circ} \mathrm{C}^{\prime} \mathrm{de}, 5000 \mathrm{~g}$ hızda 20 dakika santrifüjlenmiş ve oluşan yağ tabakası uzaklaştırılarak yağsız süt elde edilmiştir. Yağsız sütün pH'sı asetik asit (10\%) ile 4.6'ya getirilerek çöktürülen kazein proteinleri santrifüjleme işlemi ile toplanmıştır. Ayrı bir behere alınan süpernatanta $\mathrm{NaOH}(1 \mathrm{M})$ eklenerek pH 6.8'e çıkarılmış ve kesik süt suyu proteinleri çöktürülmüştür. Süpernatant 
$20^{\circ} \mathrm{C}$ 'de $8000 \mathrm{~g}$ dönüş hızında 20 dakika santrifüjlenerek kesik süt suyu proteinleri toplanmıştır. Liyofilize edilen eşek sütü, kazein ve kesik süt suyu proteinleri kullanılıncaya kadar $-20^{\circ} \mathrm{C}$ 'de saklanmıştır [19].

\subsection{Hücre kültü̈rü}

$\mathrm{Bu}$ çalışmada kullanılan hücre hatları (PC-3 ve BJ) \%10 FBS, \%1 antibiyotik / antimikotik ve $\% 1$ esansiyel olmayan aminoasitleri içeren besiyerinde (DMEM-10) $37^{\circ} \mathrm{C} \% 5 \mathrm{CO}_{2}$ ortamında tutularak çoğaltılmışlardır. Tüm hücre hatları en az $\% 80$ konfluent olana kadar inkübasyona devam edilmiş ve tripsinize edilen hücreler tripan mavisi ile boyanarak deneylerde hücre canlılığı \%90 üzerinde olan kültürler kullanılmıştır.

\subsection{MTT hücre proliferasyon testi}

Hücre canlılığını gözlemlemek için eşek sütü proteinleri ile muamele edilmiş hücrelere MTT hücre proliferasyon testi uygulanmıştır. Kısaca, tripsinizasyon işlemi ile toplanan hücreler $100 \mu \mathrm{l}$ DMEM-10 besiyeri içerisinde $1 \times 10^{4}$ hücre/kuyu içerecek şekilde 96 kuyucuklu plakanın her bir kuyucuğuna eklenmiş ve $37^{\circ} \mathrm{C} \% 5 \mathrm{CO}_{2}$ 'de 24 saat inkübe edilmiştir. İnkübasyon sonunda kuyucuklardaki besiyeri uzaklaştırılarak kuyucuklara $100 \mu \mathrm{l}$ DMEM-10 içerisinde farklı konsantrasyonlarda (200-3200 $\mu \mathrm{g} / \mathrm{ml}$ aralığında) seyreltilen eşek sütü, kazein veya kesik süt proteini eklenmiştir. Herhangi bir uygulamaya maruz bırakılmayan kontrol kuyucuklarındaki hücrelere ise sadece DMEM-10 eklenmiştir. Hücreleri içeren plakalar $37^{\circ} \mathrm{C}$ ve $\% 5 \mathrm{CO}_{2}$ 'de 24 , 48 veya 72 saat süreyle inkübatörde bekletilmiştir. İnkübasyon sonunda her kuyucuğa $10 \mu 1$ tetrazolyum boyası eklenmiş ve plaka 3 saat daha inkübatörde tutulmuştur. $\mathrm{Bu}$ süre sonunda besiyeri uzaklaştırılmış, kuyularda oluşan formazan kristalleri DMSO (100 $\mu 1 /$ kuyu) içerisinde çözülmüş ve kuyucukların absorbansı 570 nm, 690 nm (arka plan) dalga boylarında ölçülmüştür. Hücre canlılığı hesaplamalarında, $570 \mathrm{~nm}$ 'de ölçülen absorbans değerinden $690 \mathrm{~nm}$ 'de ölçülen absorbans değeri çıkarılmasıyla elde edilen değerler kullanılmıştır. Uygulama gruplarının canlılık yüzdesi sadece besiyerinin eklendiği kontrol grubu ile karşılaştırılarak hesaplanmıştır (1).

$\%$ canlllık $=\frac{\text { uygulama absorbans }}{\text { kontrol absorbans }} \times 100$

\section{5. Çizik testi}

Hücre migrasyonunu gözlemlemek ve eşek sütü ile bazı bileşenlerinin yara iyileştirme potansiyelini incelemek için BJ hücrelerine çizik testi uygulanmıştır. BJ hücreleri 24 kuyucuklu plakanın her kuyucuğuna $5 \times 10^{4}$ hücre/kuyucuk olacak şekilde eklenmiş ve 24 saat $37^{\circ} \mathrm{C} \% 5 \mathrm{CO}_{2}$ 'de inkübe edilmiştir. İnkübasyon sonunda oluşan tek katmanlı hücre tabakası $1 \mathrm{ml}$ 'lik steril pipet ucu ile doğrusal bir hat boyunca çizilmiştir. Çizim işlemi sırasında hücre tabakasından kopan hücreler besiyeri ile beraber uzaklaştırılmıştır. Kontrol grubunda kuyulara taze besiyeri eklenirken uygulama gruplarında ise besiyeri içerisinde seri dilüsyonlar halinde hazırlanan kesik süt suyu proteini, eşek sütü veya kazein proteini $(3200 \mu \mathrm{g} / \mathrm{ml})$ her kuyucuğa $500 \mu$ l olacak şekilde eklenmiştir. İnkübasyon sonunda $(0,24,48$ ve 72 'nci saatlerde) kuyucuklar fizyolojik tampon solüsyonu ile yıkanmış ve hücre tabakasında oluşturulan çizikler 1 şı mikroskobu ile fotoğraflanmıştır. Hücre migrasyon ölçümü ImageJ programı kullanılarak farklı inkübasyon süreleri için ayrı ayrı yapılmıştır. Yara kapanma yüzdesi aşağıdaki formüle göre hesaplanmıştır (2). 
\%Kapanma $=\frac{\text { başlangıç çizik alanı-t anında ölçülen çizik alanı }}{\text { başlangıç çizik alanı }} \times 100$

\subsection{Istatiksel analizler}

$\mathrm{Bu}$ çalışmada yer alan tüm deneyler birbirinden bağımsız üç tekrar halinde gerçekleştirilmiş ve grafiklerde bu deneylerden elde edilen verilerin ortalaması, hesaplanan standart sapmalar ile birlikte gösterilmiştir. Grafikler SigmaPlot 14 programı kullanılarak çizilmiş ve tüm sonuçlar Graphpad Prism 8 programı ile istatiksel olarak analiz edilmiştir. MTT testinde gruplar arasındaki farkları belirlemek için Twoway ANOVA testi kullanılmıştır ( $\mathrm{p}<0.05)$. Yara iyileştirme testinde gruplar arasındaki farklar Tukey test çoklu karşılaştırma yöntemi ile istatiksel olarak analiz edilmiştir ( $p$ $0.05)$.

\section{Sonuçlar ve tartışma}

\subsection{MTT hücre proliferasyon testi bulguları}

Farklı konsantrasyonlarda (200-400-800-1600-3200 $\mu \mathrm{g} / \mathrm{ml})$ eşek sütü, kazein veya kesik süt suyu proteini PC-3 hücre hattına ayrı ayrı uygulanmıştır. PC-3 hücreleri üzerinde eşek sütü uygulanan tüm gruplarda 24, 48 ve 72'nci saatlerde hücre canlılığında belirgin bir değişim gözlemlenmemiştir ( $p<0.05$ ). Özellikle $3200 \mu \mathrm{g} / \mathrm{ml}$ ve $1600 \mu \mathrm{g} / \mathrm{ml}$ konsantrasyonlarda 24'üncü saatte canlılık oranı \%110'a kadar ulaşmıştır (Şekil 1 A). Kesik süt suyu proteininde de eşek sütünden elde edilen sonuçlara benzer şekilde uygulanan farklı konsantrasyonlar ve saatler arasinda anlamlı bir farklılık gözlemlenmemiştir $(\mathrm{p}<0.05)$ (Şekil 1 B). Fakat kazein uygulanmış PC-3 hücre canlılığında kayda değer oranda artış görülmüştür. Özellikle 24'üncü saatteki hücre proliferasyonu incelendiğinde, $400-3200 \mu \mathrm{g} / \mathrm{ml}$ aralığındaki tüm uygulama konsantrayonları ile kontrol grubu arasında anlamlı bir fark bulunmuştur ( $\mathrm{p}<0.05$ ). Hücre proliferasyonu 48'inci saatte de gözlenmeye devam etmiştir. 72'nci saatte hücre canlılığgının \%90'ın altına düşmesi aşırı hücre büyümesi sonucu oluşan uygunsuz ortam koşullarına bağlanmaktadır (Şekil $1 \mathrm{C}$ ).

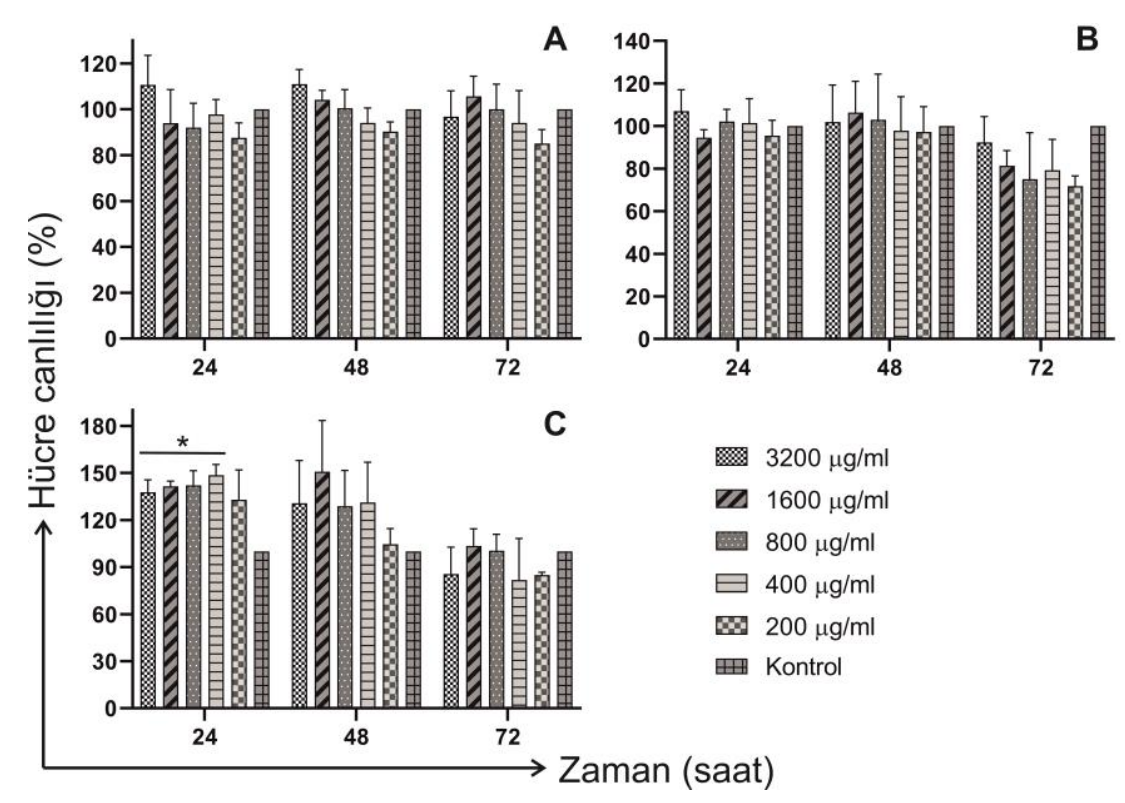

Şekil 1. PC-3 hücre hattına 200-3200 $\mu \mathrm{g} / \mathrm{ml}$ konsantrasyon aralığında uygulanan; (A) eşek sütü, (B) kesik süt suyu proteini ve (C) kazein proteini MTT proliferasyon testi sonuçları $(\mathrm{p}<0.05)$. 
Yaptığımız çalışmada, eşek sütü ve bileşenlerinin in vitro ortamda prostat kanseri hücrelerine (PC-3) antikanser aktivite göstermediği, özellikle kazein proteinin bu hücre hattında proliferasyona sebep olduğu gözlenmiştir. Elde ettiğimiz bu bulgular doğrultusunda eşek sütü ve bileşenlerinin yara iyileştirme amaçlı kullanılabileceği düşünülmüş ve insan fibroblast hücre hattı $(\mathrm{BJ})$ üzerinde çizik testi uygulanmıştır.

\section{2. Çizik testi bulguları}

Eşek sütü, kazein ve kesik süt suyu proteininin yara iyileştirme potansiyelini incelemek amacıyla BJ hücre hattında çizik testi yapılmıştır. Çizik testi deneylerinde, tüm proteinler için $3200 \mu \mathrm{g} / \mathrm{ml}$ protein konsantrasyonu kullanılmıştır. Kontrol grubu hücrelerine hiç bir muamele yapılmamış, hücre katmanında çizik oluşturulduktan sonra hücreler besiyeri içerisinde büyütülmüştür.

Iş1k Mikroskobu görüntülerine dayalı alan hesaplamaları ImageJ programı kullanılarak yapılmış olup bu görüntüler Şekil 2'de gösterilmiştir. Kontrol grubunda 0'incı saatte çizik belirgin bir şekilde görülmektedir. Işık mikroskobu görüntülerine göre 24'üncü saatte hücre migrasyonunun başladığ 1 ve 48 'inci saatte migrasyonun devam ettiği gözlemlenmiştir. Kontrol grubunda 72'nci saatin sonunda, atılan çizik halen görülebilmektedir (Şekil 2 A-D). Eşek sütü kontrol grubu ile kıyaslandığında eşek sütünün çiziği daha hızlı kapattığı gözlemlenmiştir. Deneyde 24 ve 48 'nci saatte belirgin bir hücre migrasyonu olduğu görülmektedir. Çizik 24'üncü saatte belirgin bir şekilde kapanmış ve 48'nci saatte neredeyse tamamen yok olmuştur. 72'nci saatte çiziğin atıldığ 1 yer belli olmayacak şekilde kapanma gözlemlenmiştir (Şekil 2 E-H). Kazein uygulanan çizik görüntülerinde 24'üncü saatte hücre migrasyonunun hızlı olduğu saptanmıştır. Çizik izi 48'nci saatin sonunda belli olmayacak şekilde, 72'nci saatin sonunda ise neredeyse tamamen kapanmıştır (Şekil 2 I-L). Kesik süt suyu proteini de eşek sütü ve kazeine benzer şekilde çiziğin hızlı bir şekilde kapandığı gözlenmiştir (Şekil 2 M-P).

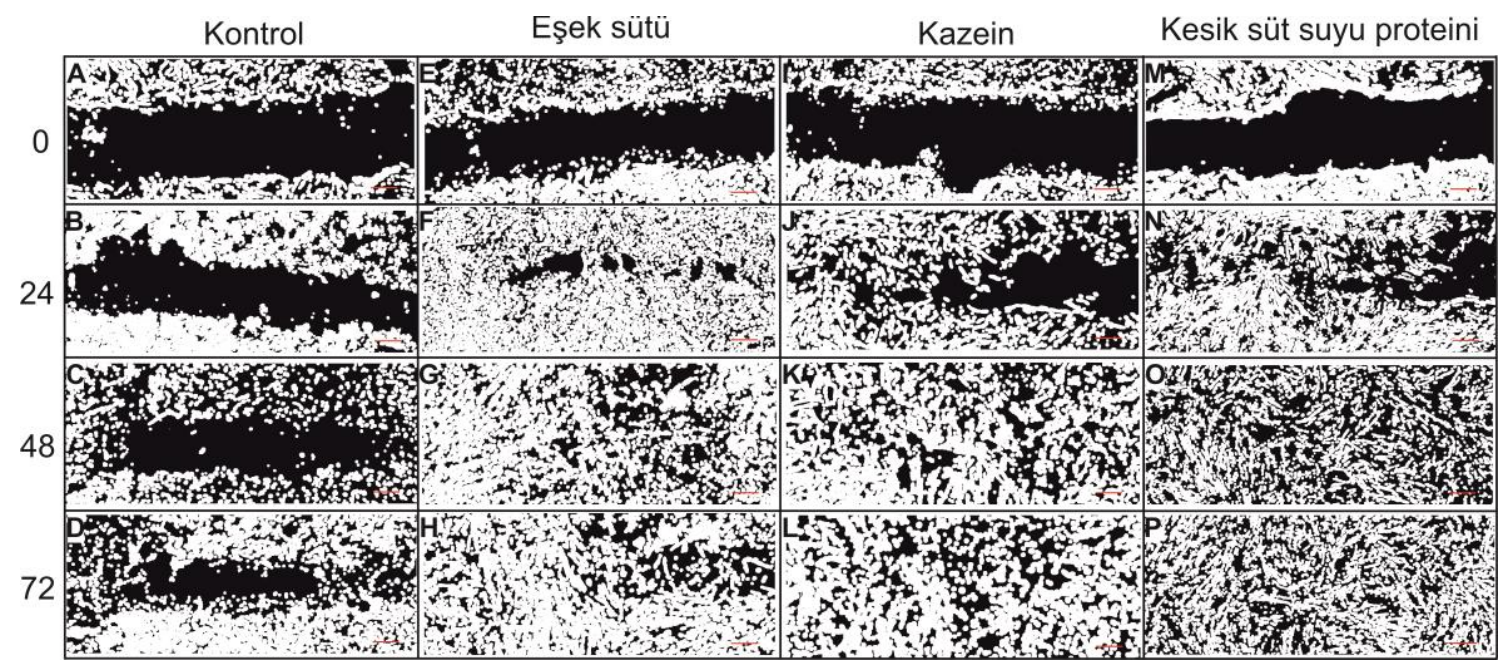

Şekil 2. BJ hücre hattına uygulanan; (A-D) kontrol, (E-H) eşek sütü, (I-L) kazein ve (M-P) kesik süt suyu proteininin çizik testi sonucunda ImageJ programında işlenmiş 1şık mikroskobu görüntüleri (sırasıyla 0, 24, 48 ve 72 'nci saat). Şekiller (A-P) içerisindeki ölçek barları $200 \mu \mathrm{m}$ uzunluğu göstermektedir.

Daha sonra 24, 48 ve 72'nci saatlerdeki çizik alanları 0'ıncı saatteki alana oranlanarak her ajan için ayrı ayrı çizik kapanma yüzdesi hesaplanmıştır (Şekil 3). Kontrol grubunda 
oluşturulan çizik 24'üncü saatin sonunda \%10 kapanırken, bu oran eşek sütünde $\% 65$, kazeinde $\% 80$ ve kesik süt suyu proteininde $\% 70$ olarak görülmektedir. Aynı çizikler; 48 'inci saatin sonunda kontrol grubunda $\% 30$, eşek sütünde $\% 85$, kazeinde $\% 90$ ve kesik süt suyu proteininde \%80 kapanırken, 72'nci saatin sonunda kontrol grubunda $\% 60$, eşek sütünde $\% 90$, kazeinde $\% 90$ ve kesik süt suyu proteininde $\% 90$ kapanmıştır. Analiz sonuçlarına göre, 24'üncü saatin sonunda kontrol grubundaki çizik kapanma yüzdesi eşek sütü, kazein ve kesik süt suyu proteinlerinin uygulandığı gruplardaki çizik kapanma yüzdelerinden anlamlı bir şekilde farklı olduğu saptanmıştır $(\mathrm{p}<0.05)$.

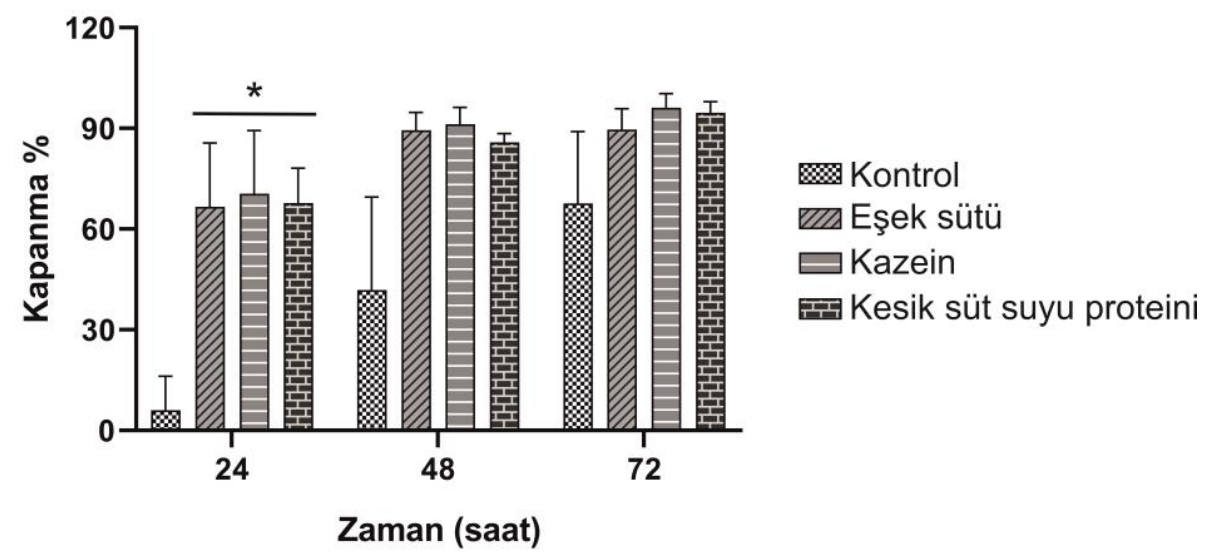

Şekil 3. Kontrol, eşek sütü, kazein ve kesik süt suyu proteini $(3200 \mu \mathrm{g} / \mathrm{ml})$ uygulanan BJ hücrelerinde çizik kapanma yüzdeleri $(\mathrm{p}<0.05)$.

Yaygın olarak tükettiğimiz yiyeceklerin içeriğinde bolca bulunan doğal aktif ajanlar; $i$ ) kolay erişilebilir olmaları, ii) ucuz olmaları, iii) tüketici tarafından daha çabuk kabul görmeleri ve $i v$ ) düşük sitotoksisiteye sahip olmaları gibi sebeplerden dolayı eski zamanlardan günümüze kadar yara iyileştirmeden kanser tedavisine kadar birçok hastalığın tedavisinde kullanılmışlardır [20-22].

Yaptı̆̆ımız çalışmada, tüketimi yapılabilen doğal besinlerden biri olan eşek sütü ve bu sütün içeriğinde bulunan kazein ve kesik süt suyu proteinlerinin prostat kanseri hücre hattı üzerindeki antikanser aktivitesi ilk defa test edilmiştir. Farklı memeli türlerinden elde edilen sütlerin in vitro ortamda çeşitli kanser hatları üzerinde denendiği çalışmalar literatürde mevcuttur [19,23-26]. Bazı çalışmalarda memeli sütleri veya içerikleri antikanser aktivite gösterirken [19,23,24,27], bazı çalışmalarda ise bizim sonuçlarımıza benzer şekilde hücre proliferasyonu gözlenmiştir [25]. Kısrak, eşek, inek, deve sütlerinin ve bu sütlerden izole edilen kazein ve kesik süt suyu proteinlerinin insan meme kanseri (MCF-7) hücre hattı üzerinde sitotoksik etki gösterdikleri sonucuna ulaşılmıştır [19]. Park ve arkadaşlarının yaptığı çalışmada ise sığır sütünün ve kazeinin farklı hücre hatları üzerinde proliferasyonuna bakılmıştır. Çalışmanın sonucunda, $\alpha$ kazein ve total kazeinin $(0,1$ ve $1 \mathrm{mg} / \mathrm{mL})$ normal prostat hücre hattında (RWPE1), insan embriyonik hücre hattında (HEK-293), akciğer kanseri hücre hattında (A459), mide kanseri hücre hattında (SN4484), meme kanseri hücre hattında (MCF-7) proliferasyona etki etmediği görülmüştür. Aynı çalışmada $1 \mathrm{mg} / \mathrm{ml} \alpha$-kazein ile muamele edilen prostat kanseri hücre hattında (PC-3) \%166 ve metastatik prostat kanseri hücre hattı (LNCaP) üzerinde \%142 proliferasyonu arttırdığ 1 belirtilmiştir [25]. Bu çalışmada yer alan prostat kanseri hücreleri üzerindeki in vitro sonuçlar çalışmamızda eşek sütü kazein proteininde bulduğumuz PC-3 hücre canlılığındaki artışa (\%142) benzerlik göstermektedir. Eşek sütünün antikanser aktivitenin incelendiği in vitro ve in vivo 
çalışmalarda farklı bulgular rapor edilmiştir. Yapılan bir çalışmada eşek sütünün in vitro ortamda akciğer kanseri hücre hattında sitotoksisite ve genotoksisiteye sebep olduğu belirtilirken [26], diğer bir çalışmada ise eşek sütü ile beslenen Swiss albino fare türünde tümör hacminin kontrol grubuna kıyasla \%68,98 arttı̆̆ 1 bildirilmiştir [28].

Kesik süt suyu proteinin zengin sistein amino asidi içeriğinin ve yüksek besin değerine sahip olmasının bağışıklık sitemini dolaylı yoldan olumlu yönde etkilediği tartışılmaktadır. Bakır (Zn) ve selenyum (Se) ile zenginleştirilmiş kesik süt suyu proteinin kemoterapi gören kanser hastaları tarafından besin olarak tüketildiğinde, hastaya bol miktarda sistein amino asidi sağladığı, sisteine bağlı olarak gluthation (GSH) miktarının arttığı ve yüksek besin değeri sayesinde hastalarda bağışıklık yanıtın kuvvetlendiği belirtilmiştir [29]. Eşek sütünün de bağışıklık sisteminde olumlu etkilere sebep olduğu ve hastalıklara karşı direnci arttırdığını gösteren çalışmalar mevcuttur [30,31,32]. Kanserli hücrelerde GSH oranının bulunduğu çevreye göre 100-1000 fazla olduğu ve artan GSH miktarının neoplastik dokuyu kemoterapötiklere karşı daha dirençli hale getirdiği düşünülmektedir [33]. Sonuç olarak, yaptığımız çalışma ve literatür çalışmaları birlikte değerlendirildiğinde kanserli hastaların kesik süt proteini tüketimi kanserle savaşımda ilaç olarak kullanılabileceği fikrini zayıflatmaktadır. Eşek sütü gibi proteince zengin süt ürünlerinin tümörlü dokuyu yok etmediği, fakat yüksek besin içeriği sayesinde bağışıklık sistemini olumlu yönde etkilediği ve kemoterapi gören kanser hastalarının daha iyi beslenmesini sağladı̆̆

Çalışmamızın bir diğer özgün değeri ise eşek sütünün in vitro çizik testi ile yara kapama potansiyelinin araştırılmasıdır. Literatürde bazı memeli sütlerinin in vitro ve in vivo ortamlarda yara kapama aktivitelerinin test edildiği çalışmalar mevcuttur. Yapılan bir çalışmada, düşük yağ içerikli inek süt proteinlerinin ve kesik süt suyu proteinlerinin tavşanlarda yara kapanma hızını arttırdığı sonucuna ulaşılmıştır. İnek sütünün ve bileşenlerinin hücre onarım sürecini hızlandırdığı ve yara iyileştirme üzerinde olumlu etkisi olduğu görülmüştür [27]. Başka bir çalışmada, deve sütünden elde edilen kesik süt suyu proteininin diyabetik farelerde yaranın daha çabuk kapanmasına sebep olduğu belirtilmiştir [34]. Deve kesik süt suyu proteininin fibroblastların epitelizasyonunu ve proliferasyonunu uyardığ 1 , hatta denatüre edilmemiş kesik süt suyu proteininin kolajen üretimine yardımcı olduğu bildirilmiştir [35]. Deve sütünden elde edilen kesik süt suyu proteini ile yapılan başka çalışmalarda da benzer şekilde diyabetik farelerde yara iyileşme sürecinin kısaldığı ve kolajen ekspresyonunun arttığ sonucuna ulaşılmıştır [36,37]. Cerrahi yara iyileşme sürecinin incelendiği bir çalışmada ise kesik süt suyu proteini ile beslenen farelerde serbest radikal birikimini önlendiği, inflamasyonun kontrol altına alındığı ve yara iyileşme sürecinin hızlandığı gözlenmiştir [38]. Eşek sütünün de düşük yağ oranına sahip olması [39] yara iyileştirme potansiyelini destekler niteliktedir.

Yaptığımız çalışmada, MTT hücre proliferasyon testi sonucunda eşek sütü, kazein ve kesik süt suyu proteininin in vitro ortamda PC-3 hücre hattı üzerinde proliferatif etki gösterdiği bulunmuştur. Bu bulgular doğrultusunda, insan fibroblast hücre hattı üzerinde in vitro çizik testi kullanılarak bu ajanların $(3200 \mu \mathrm{g} / \mathrm{ml})$ yara iyileştirme potansiyelleri incelenmiştir. Kontrol grubu ile eşek sütü, kazein ve kesik süt suyu proteini arasında anlamlı farklılık bulunmuştur. Deneysel sonuçlara bakılarak eşek sütü, kazein ve kesik süt suyu proteininin antikanser aktivitesinden ziyade yara iyileştirme üzerinde olumlu etki sergilediği görülmektedir. Elde edilen bulguların in vivo çalışmalar ile 
desteklenmesiyle, eşek sütünün katma değeri yüksek ticari ürüne dönüştürülme potansiyeli yüksektir.

\section{Teşekkür}

Bu çalışma TÜBİTAK 2209-A Üniversite Öğrencileri Araştırma Projeleri Destekleme Programı tarafından desteklenmiştir.

\section{Kaynaklar}

[1] https://www.cancer.gov/about-cancer/understanding/what-is-cancer, (03.12.2019).

[2] Twilley, D. ve Lall, N., Chapter 7 - The Role of Natural Products From Plants in the Development of Anticancer Agents in Mandal, S. C., Mandal, V. ve Konishi, T., Natural Products and Drug Discovery: An Integrated Approach, Elsevier, 139-178, (2018).

[3] https://hsgm.saglik.gov.tr/depo/birimler/kanserdb/istatistik/Turkiye_Kanser_Istatistikleri_2015.pdf, (03.12.2019)

[4] Kaur, K., Kumar, V., Sharma, A. K. ve Gupta, G. K., Isoxazoline containing natural products as anticancer agents: A review, European Journal of Medicinal Chemistry, 77, 121-133, (2014).

[5] Sah, B. N. P., Vasiljevic, T., McKechnie, S. ve Donkor, O. N., Identification of Anticancer Peptides from Bovine Milk Proteins and Their Potential Roles in Management of Cancer: A Critical Review, Comprehensive Reviews in Food Science and Food Safety, 14, 123-138, (2015).

[6] Khazir, J., Riley, D. L., Pilcher, L. A., De-Maayer, P. D. ve Mir, B. A., Anticancer Agents from Diverse Natural Sources, 9, 11, 1655-1669, (2014).

[7] Kurtoğlu, H. ve Karataş, A., Yara Tedavisinde Güncel Yaklaşımlar: Modern Yara Örtüleri, Ankara Eczacılık Fakültesi Dergisi, 38, 3, 211-232, (2009).

[8] Yazar, H. ve Karaca, İ., Yumuşak Dokuda Yara İyileşmesi, Etkileyen Faktörler ve Skar Revizyonu, Atatürk Üniv. Diş. Hek. Fak. Dergisi,15, 152-161, (2016).

[9] Guo, S., ve DiPietro, L. A., Factors Affecting Wound Healing, Journal of Dental Research, 89, 3, 219-229, (2010).

[10] Pucar, L. B., Kovac, A., Detel, D., Buljevic, S., Pugel, P. E. ve Varljen, J., Wound Healing Process, Diabetes and Implications of Dipeptidyl Peptidase IV (DPPIV/CD26), Journal of Tissue Science \& Engineering, 8, 3, (2017).

[11] Pradhan, L., Andersen, N. D., Nabzdyk, C., LoGerfo, F. W. ve Veves, A., Wound-healing Abnormalities in Diabetes and New Therapeutic Interventions, US Endocrine Disease, 68-72, (2007).

[12] Garraud, O., Hozzein, W. N. ve Badr, G., Wound healing: time to look for intelligent, 'natural' immunological approaches?, BMC Immunology, 18, 1, 23, (2017).

[13] Krishnankutty, R., Iskandarani, A., Therachiyil, L., Uddin, S., Azizi, F., Kulinski, M., Bhat, A. A. ve Mohammad, R. M., Anticancer Activity of Camel Milk via Induction of Autophagic Death in Human Colorectal and Breast Cancer Cells, Asian Pacific Journal of Cancer Prevention, 19, 12, 3501-3509, (2018).

[14] Budak, Ş. ve Gürsel, A., Alternatif Bir Süt: Eşek Sütü, GIDA, 37, 4, 243-250, (2012) 
[15] Li, L., Liu, X. ve Guo, H., The nutritional ingredients and antioxidant activity of donkey milk and donkey milk powder, Food Science and Biotechnology, 27, 393-400, (2018).

[16] Polidori, P. ve Vincenzetti, S., Protein Profile Characterizaytion of Donkey Milk in Hurley, W., Milk Protein, In TechOpen, 215-232, (2012).

[17] Devi, S., Gandhi, K., Rana, S., Arora, S. ve Kapila S., Donkey Milk: A Very Recent Nutritional Pharmafood, Indian Dairyman, 70, $72-77$ (2018).

[18] Taşçı, F., Eşek Stünün Özellikleri ve Gıda Alerjilerinde Kullanımı, Uludağ Üniversitesi Veterinerlik Fakültesi Dergisi, 30, 2, 39-44, (2011).

[19] Sharitatikia, M., Behbahani, M. ve Mohabatkar, H., Anticancer activity of cow, sheep, goat, mare, donkey and camel milks and their caseins and whey proteins and in silico comparison of the caseins, Molecular Biology Research Communications, 6, 2, 57-64, (2017).

[20] Dutta, S., Mahalanobish, S., Saha, S., Ghosh, S. ve Sil, P. C., Natural products: An upcoming therapeutic approach to cancer, Food and Chemical Toxicology, 128, 240-255, (2019).

[21] Lalitha, L. J., Sales, T. J., Prince.P.Clarance, P.Agastian, Kim, Y. O., Mahmoud, A. H., Mohamed, S. E., Tack, J. C., Na, S. W. ve Kim, H. J., In-vitro phytopharmacological and anticancer activity of Loranthus Longiflorus Desv. Var. Falcatuskurz against the human lung cancer cells, Journal of King Saud University - Science, 32, 1246-1253, (2020).

[22] Premarathna, A. D., Ranahewa, T. H., Wijesekera, S. K., Wijesundara, R. R. M. K. K., Jayasooriya, A. P., Wijewardana, V. ve Rajapakse, R. P. V. J., Wound healing properties of aqueous extracts of Sargassum illicifolium: An in vitro assay, Wound Medicine, 24, 1-7, (2019).

[23] Mao, X., Gu, J., Sun, Y., Xu, S., Zhang, X., Yang, H. ve Ren, F., Antiproliferative and anti-tumour effect of active components in donkey milk on A549 human lung cancer cells, International Dairy Journal 19, 11, 703-708, (2009).

[24] Al-Mudallala, N. H., Tahab, A. A., Abbas, M. Q. ve Mohammedd, F. I., Growth Inhibition and Anti-Cancer Activity of the Human Hepatocarcinoma HepG2 Cell Line in Vitro Study Using Human, Camel and Cow Milk, International Journal of Sciences: Basic and Applied Research , 3, 2, 40-47, (2016).

[25] Park, S. W., Kim, J. Y., Lee, S. J. ve Chung, M. K., A Milk Protein, Casein, as a Proliferation Promoting Factor in Prostate Cancer Cells, The World Journal of Men's Health, 32, 2, 76-82, (2014).

[26] Akca, C., Vatan, O., Yilmaz, D., Huriyet, H., Cinkilic, N. ve Cavas, T., In vitro cytotoxic and genotoxic effects of donkey milk on lung cancer and normal cells lines, Czech Journal of Food Sciences, 37, 29-35, (2019).

[27] Hemmati, A. A., Larki-Harchegani, A., Shabib, S., Jalali, A., Rezaei, A. ve Housmand, G., Wound healing property of milk in full thickness wound model of rabbit, International Journal of Surgery, 54, 133-140, (2018).

[28] Esener, O. B. B., Balkan, B. M., Armutak, E. I., Uvez, A., Yildiz, G., Hafizoglu, M., Yilmazer, N., ve Gurel-Gurevin, E., Donkey milk kefir induces apoptosis and suppresses proliferation of Ehrlich ascites carcinoma by decreasing iNOS in mice, Biotechnic and Histochemistry, 93, 424-431, (2018).

[29] Bumrungpert, A., Pavadhgul, P., Nunthanawanich, P., Sirikanchanarod, A. ve Adulbhan, A., Whey Protein Supplementation Improves Nutritional Status, Glutathione Levels, and Immune Function in Cancer Patients: A Randomized, 
Double-Blind Controlled Trial, Journal of Medicinal Food, 21, 612-616, (2018).

[30] Tafaro A., Magrone, T., Jirillo, F., Martemucci, G., D’Alessandro, A. G., Amati, L. ve Jirillo, E., Immunological properties of donkey's milk: its potential use in the prevention of atherosclerosis, Current Pharmaceutical Design, 13, 36, 3711-3717, (2007).

[31] Jirillo, F., Jirillo, E. ve Magrone, T., Donkey's and goat's milk consumption and benefits to human health with special reference to the inflammatory status, Current Pharmaceutical Design, 16,7, 859-863, (2010).

[32] Yvon, S., Olier, M., Leveque, M., Jard, G., Tormo, H., Ali, D., Lekhal, H., Peter, M. ve Eutamène, H., Donkey milk consumption exerts anti - inflammatory properties by normalizing antimicrobial peptides levels in Paneth' $\mathrm{s}$ cells in a model of ileitis in mice, European Journal of Nutrition, (2016).

[33] Traverso, N., Ricciarelli, R., Nitti, M., Marengo, B., Furfaro, A. L., Pronzato, M. A., Marinari, U. M. ve Domenicotti, C., Role of glutathione in cancer progression and chemoresistance, Oxidative Medicine and Cellular Longevity, (2013).

[34] Badr, G., Camel whey protein enhances diabetic wound healing in a streptozotocin-induced diabetic mouse model: The critical role of $\beta$-Defensin-1, -2 and -3, Lipids in Health and Disease, 12, 1, (2013).

[35] Badr, G., Supplementation with undenatured whey protein during diabetes mellitus improves the healing and closure of diabetic wounds through the rescue of functional long-lived wound macrophages, Cell. Cellular Physiology and Biochemistry, 29, 571-582, (2012).

[36] Salam, A., Ebaid, H., Al-Tamimi, J. ve Alhazza, İ., Enhancement of Wound Healing by Un-denatured Camel Whey Proteins in Protein Malnourished Mice, Pakistan Journal of Zoology, 48, 1, 1-9, (2016).

[37] Ebaid, H., Salem, A., Sayed, A. ve Metwalli, A., Whey protein enhances normal inflammatory responses during cutaneous wound healing in diabetic rats, Lipids In Health And Disease, 10, 235 (2011).

[38] Sagliyan, A., Ceribasi, A. O., Gunay, C., Han, M. C., Benzer, F. ve Kandemir, M. F., Effects of dietary supplementation with whey proteins on surgical wound healing in rats, Revue de médecine vétérinaire, 161, 455-462, (2010).

[39] Souroullas, K., Aspri, M. ve Papademas, P., Donkey milk as a supplement in infant formula: Benefits and technological challenges, Food Research International, 109, 416-425, (2018). 